\title{
FLOWERING, NECTAR SECRETION, POLLEN SHED AND INSECT FORAGING ON Aquilegia vulgaris L. (Ranunculaceae)
}

\author{
Bożena Denisow, Sebastian Antoń \\ Department of Botany, University of Life Sciences in Lublin, Akademicka 15, 20-950 Lublin, Poland, \\ e-mail: bozena.denisow@up.lublin.pl
}

Received: 16.09.2011

\begin{abstract}
This study on blooming biology, nectar secretion, pollen production and insect visitation of Aquilegia vulgaris L. was carried out in 2009 and 2011 in Lublin. The peak of flower opening during the day was between 5.00 and 7.00 (GMT +2 ). The flowers are protandrous with the female phase beginning approx. on the $3^{\text {rd }}$ day of anthesis. The dynamics of nectar secretion and pollen shed from anthers (progressing from the central part of the androecium outwards) support the reproductive system. The amount of nectar accumulated in the spurs increased from the bud stage and was the highest in the phase with approx. $3 / 4$ of dehisced anthers, usually on the $3^{\text {rd }}$ day of flower life. Then, towards the end of anthesis, the amount of secreted and accumulated nectar decreased. The number of anthers developed per flower varied from 41 to 61 (mean = 49.1). The mass of pollen per 100 anthers averaged $6.7 \mathrm{mg}$. Pollen production per flower $($ mean $=3.28 \mathrm{mg}$ ) slightly varied between years and was mainly correlated with the number of developed anthers. Estimated pollen yield was $1.69 \mathrm{~g}$ per $\mathrm{m}^{2}$ and sugar yield $1.22 \mathrm{~g}$ per $\mathrm{m}^{2}$. Species from the genus Bombus were the main flower visitors, with $B$. terrestris being the most frequent forager.
\end{abstract}

Key words: dynamics of blooming, nectar secretion, pollen production, Aquilegia vulgaris L.

\section{INTRODUCTION}

Aquilegia vulgaris L. (Ranunculaceae) is native to Eurasia and is distributed in north temperate regions in America. This perennial creates dense patches on meadows, along river banks, on a range of damp calcareous soils, including cliffs, and is found in deciduous forests located up to $1200 \mathrm{~m}$ a.s.l. (L a v e r $\mathrm{gne}$ et al. 2005). The species is protected by law in Poland. Among beekeepers, the Ranunculace species are regarded not very attractive for Apis mellifera, as reports of the toxicity of their pollen are known. Most Ranunculaceae flowers offer no nectar, only pollen, but numerous species create trophic niches for different wild pollinators (e.g. Osmia, Megachile, Bombus, Andrena). Szklanowska (1995) found pollen production up to $62 \mathrm{~kg}$ per ha for Ranunculus acer L. on meadows. The significance of an early pollen source provided by Adonis vernalis L. in xerothermic swards was emphasized by De n i s o w and Wrze sień (2006) as well as Denisow et al. (2008). Ornamental plants, due to high pollen production, are recommended to be grown in insect-friendly gardens (Ź uraw and Denisow, 2002; B ożek, 2003; Szklanowska et al. 2003; Denisow and Bożek, 2006; Kocira and Laskowska, 2006; R y siak and Żuraw, 2011).

Pollinator preferences are based on different flower features (Percival, 1961; B aker 1975; Faegrii and van der Pij1, 1979; Fussel and Corbet 1992; Stpiczyńska, 2004; Weryszko-Chmielewska and Dmitruk, 2009; Wróblews ka, 2010; Den is ow, 2011; Żuraw, 2011). Nectar secretion and composition of Aquilegia are described by Canto et al. 2007, while some aspects of differences in biology and distribution are shown by Medrano et al. 2006.

The aim of the present study was to establish the rate of nectar secretion and pollen production of Aquilegia vulgaris L.; additional interest was attached to the observations of blooming and pollinator composition.

\section{MATERIALS AND METHODS}

The observations were carried out in 2009 and in 2011 in the UMCS Botanical Garden in Lublin. 
Aquilegia vulgaris $\mathrm{L}$. was grown in the alpine section on loess soil, $\mathrm{pH}$ 6-7, at a site fully exposed to the sun.

Flowering time and duration were noted and observations of the diurnal dynamics of blooming were made according to the protocol described by D e n i s ow (2009). Simultaneously to the flowering observations, the pattern and intensity of insect visitation were noted. The number of all visiting insects foraging per unit area was counted. The development of flower and the the dynamics of anther dehiscence were noted at one-hour intervals $(\mathrm{GMT}+2 \mathrm{~h})$ and the number of dehiscent anthers was counted. The abundance of flowering was established on the basis of stems recorded per $1 \mathrm{~m}^{2}$ and the number of flowers developed per stem $(n=15)$. The flower life-span was defined as the period from bud opening until corolla wilting.

Nectar secretion was measured by the micropipette method. Nectar was extracted at different stages of flower life (J a błoński, 2002). Samples were collected from flowers 1) at bud stage, 2) with c.a. $1 / 2$ of dehisced anthers, 3 ) with c.a. $3 / 4$ of dehisced anthers $-3^{\text {rd }}$ day of flower life, 4) with all anthers dehisced $-4^{\text {th }}$ day of flower life-span. Sugar concentration measurements were made with an Abbe refractometer and sugar mass was calculated. To exclude insect visits, flowers were bagged with gauze covers. Pollen production was assayed using the method of $\mathrm{S} \mathrm{z} \mathrm{k} \mathrm{la} \mathrm{-}$ n ow s k a (1995). Dry weight of anthers with pollen and pollen mass were determined at the full bloom stage. The mass of pollen produced was calculated for 100 anthers, 10 flowers, and per unit area.

The data were analyzed statistically using ANOVA. The significance between means was examined by Duncan's test at $\alpha=0.05$. Statistica software version 6 was applied.

\section{RESULTS}

Flowering and nectar secretion. During the years of the study, the average blooming season of Aquilegia vulgaris L. was from mid-May till the end of July. Aquilegia vulgaris was characterized by an early flower opening pattern with the peak between 5.00 and 7.00 (GMT +2) (Fig. 1). Up to $40 \%$ of opened flowers were observed. During the rest of the day, the flowers developed steadily and $5-10 \%$ of the daily number opened during one-hour intervals. Starting from 16.00, the process declined markedly. The mean number of stems established was 21.9 per $1 \mathrm{~m}^{2}$ (Table $1)$. The stems were branched and the number of flowers ranged from 5 to 61 per stem (mean=24.2). The flower is perfect, complete, with five petals elongated into spurred segments (Fig. 2 a-c). The flowers are protandrous, with the female phase beginning approx. on the $3^{\text {rd }}$ day of anthesis (Fig. 3 a-c). The individual nectaries are separately situated in floral spurs and nectar is accumulated in the chamber at the base of the spurs in different amounts. Usually, 1-2 spurs per flower were nectarless. The floral spur length was changing during flower development. Measured from the floral spur base to the entrance of the throat of the flower, the spur length was the shortest $($ mean $=11.2 \mathrm{~mm}$, $\mathrm{SD}=1.44)$ at the beginning of anthesis and the longest (mean $=16.8 \mathrm{~mm}, \mathrm{SD}=2.11$ ) at the end of flower life-span. Together with the spur lengthening, the amount of accumulated nectar increased and was the highest at the stage with approx. $3 / 4$ of dehisced anthers, usually on the $3^{\text {rd }}$ day of flower life. Then, towards the end of anthesis, the amount of secreted and accumulated nectar decreased. Nectar resorption occurred concurrently to the advanced process of anther dehiscence (Fig. 4). The flower life-span, from bud opening until wilting, was completed in 4-5 days.

Pollen shed and insect visits. The number of anthers developed per flower varied from 41 to 61 $($ mean $=49.1)$. Pollen release began simultaneously with flower opening at about $5.00(\mathrm{GMT}+2 \mathrm{~h})$ and progressed steadily with approx. 5\% of dehiscent anthers in one-hour intervals (Fig.1). The release of pollen lasted 2.3 days per flower, on average. Anther dehiscence started in the central part of the androecium and progressed outwards (Fig. 3d). The number of anthers developed per flower differed significantly between years $($ mean $=49.1)$ (Table 2). Dry weight of stamen heads differed considerably between years and was lower in 2009, compared with 2011. Coincidentally, the mass of pollen produced was high in 2009 which was related to the percentage proportion of pollen per 100 anthers. Pollen mass per 100 anthers averaged $6.7 \mathrm{mg}$. Pollen production per flower (mean $=3.28 \mathrm{mg}$ ) slightly varied between years and was correlated mainly with the number of developed anthers. The estimated pollen yield was $1.69 \mathrm{~g}$ per $\mathrm{m}^{2}$ and sugar yield $1.22 \mathrm{~g} \mathrm{per}^{2}$ (Fig. 5).

Bombus spp. were the main visitors, with $B$. terrestris being the most frequent forager. Among other pollinators, Apis mellifera, solitary bees, Diptera, and wasps were sporadically observed. The activity of Bombus spp. began at about 5.00 and lasted till late evening. The most intensive foraging activity was observed from early morning till midday, accounting for approx. $70 \%$ of all visits performed during the entire day (Fig. 1). Bumblebees collected nectar and pollen but the nectar was a more attractive goal. 
Table 1.

Flowering abundance of Aquilegia vulgaris L. in 2009 and 2011 in Lublin

\begin{tabular}{|c|c|c|c|c|}
\hline \multirow{3}{*}{ Year } & \multirow{3}{*}{ Number of shoots per $\mathrm{m}^{2}$} & \multicolumn{3}{|c|}{ Number of flowers } \\
\hline & & \multicolumn{2}{|c|}{ per shoot } & \multirow{2}{*}{ per $\mathrm{m}^{2}$} \\
\hline & & $\min -\max$ & mean $\pm \mathrm{SD}$ & \\
\hline 2009 & 19.7 & $9-61$ & $30.4 \pm 20.5$ & 598.8 \\
\hline 2011 & 24.0 & $5-48$ & $17.9 \pm 9.1$ & 429.6 \\
\hline Mean & 21.9 & & 24.2 & 514.3 \\
\hline
\end{tabular}

Table 2.

Number of anthers and weight of pollen produced by Aquilegia vulgaris L. in Lublin

\begin{tabular}{|c|c|c|c|c|c|c|c|}
\hline \multirow{3}{*}{ Year } & \multirow{2}{*}{\multicolumn{2}{|c|}{$\begin{array}{c}\text { Number of anthers } \\
\text { per flower }\end{array}$}} & \multirow{3}{*}{$\begin{array}{c}\begin{array}{c}\text { Dry weight of } \\
100 \text { anthers with } \\
\text { pollen }\end{array} \\
\text { mean } \pm \text { SD }\end{array}$} & \multicolumn{2}{|c|}{$\begin{array}{l}\text { Pollen mass } \\
\text { per } 100 \text { anthers }\end{array}$} & \multirow{3}{*}{$\begin{array}{l}\text { Pollen mass } \\
\text { per } 10 \text { flowers } \\
\text { mg }\end{array}$} & \multirow{3}{*}{$\begin{array}{c}\text { Viability } \\
\%\end{array}$} \\
\hline & & & & \multirow{2}{*}{$\begin{array}{c}\% \\
\text { of dry weight }\end{array}$} & \multirow{2}{*}{$\begin{array}{c}\mathrm{mg} \\
\text { mean } \pm \mathrm{SD}\end{array}$} & & \\
\hline & $\min -\max$ & mean $\pm \mathrm{SD}$ & & & & & \\
\hline 2009 & $41-51$ & $47.4_{a} \pm 3.7$ & $14.5 \pm 4.6$ & $51.7_{\mathrm{b}}$ & $7.2_{b} \pm 0.2$ & 34.1 & $92.3_{\mathrm{a}}$ \\
\hline 2011 & $42-61$ & $50.8_{b} \pm 5.7$ & $21.1 \pm 1.8$ & $29.4_{a}$ & $6.2_{\mathrm{a}} \pm 1.7$ & 31.4 & $96.4_{a}$ \\
\hline Mean & & 49.1 & 17.8 & 40.6 & 6.7 & 32.8 & 94.4 \\
\hline
\end{tabular}

$\mathrm{a}-\mathrm{b}$ - means followed by the same small letters are not significantly different between years at $a=0.05$ (Duncan's test), SD- standard deviation

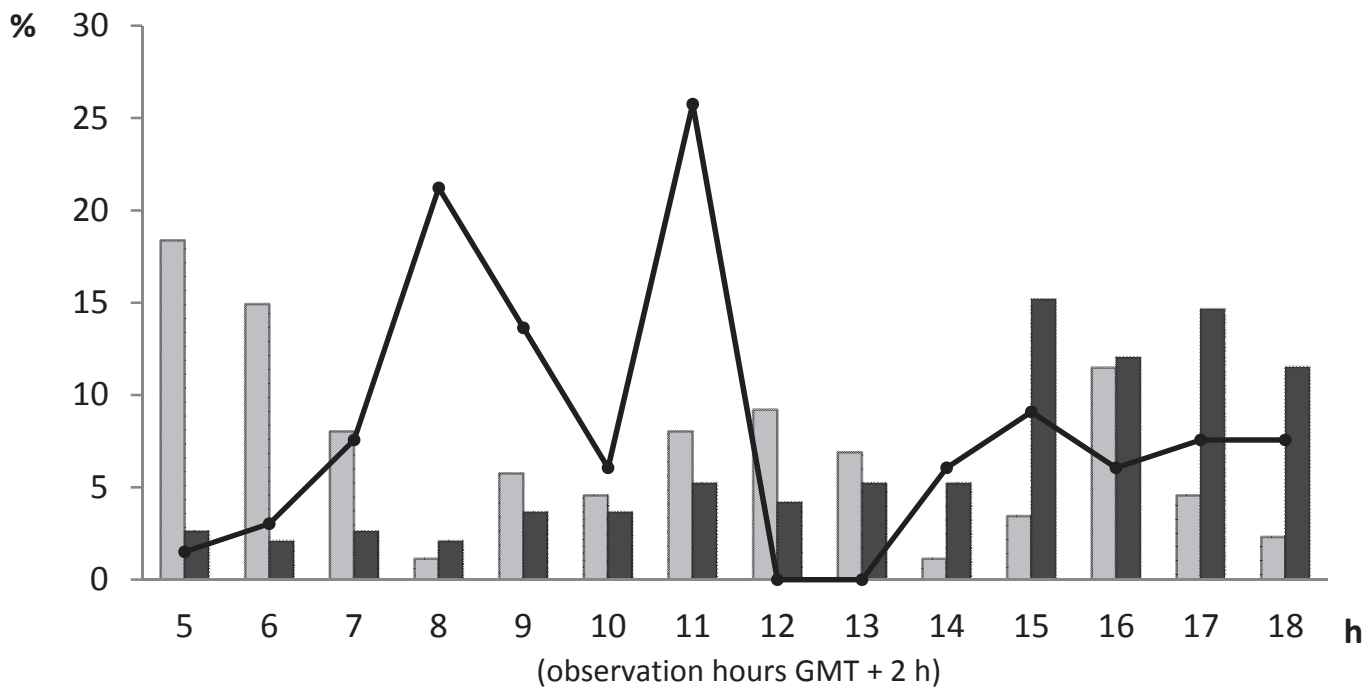

number of flowers blooming in one-hour intervals in relation to the sum of flowers blooming in the whole day in \%

number of bursting anthers in one-hour intervals in realtion to the sum of bursting anthers in whole day in \%

$\longrightarrow$ number of bumblebees showed analogically as flowers and anthers

Fig. 1. Diurnal dynamics of blooming, pollen production and bumblebee foraging on Aquilegia vulgaris L. in Lublin. 

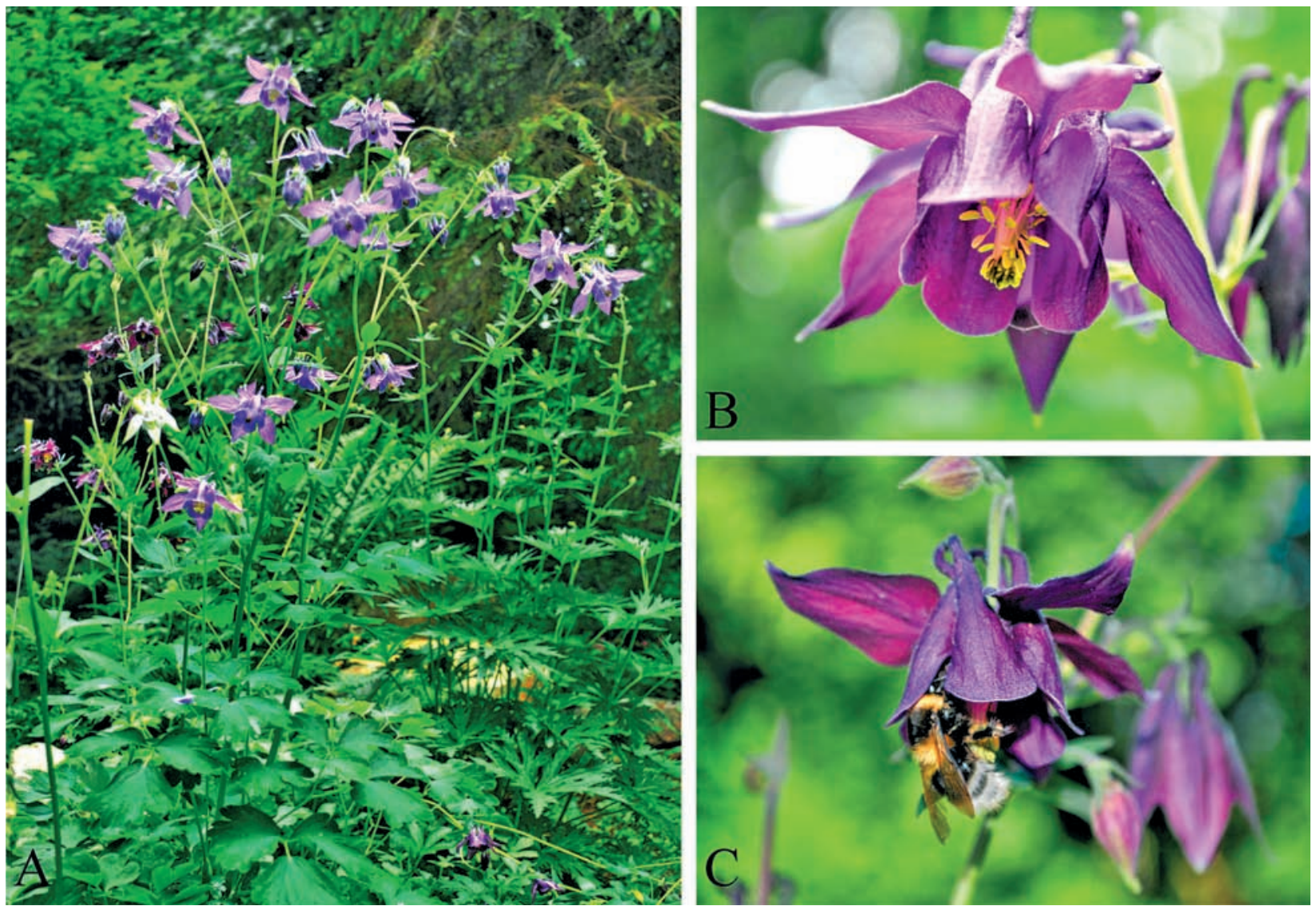

Fig. 2. Aquilegia vulgaris L. (A) at full bloom in the experimental plot in 2011; (B) a perfect, complete flower on the 2nd day of flower life-span; (C) Bombus sp. collecting nectar.

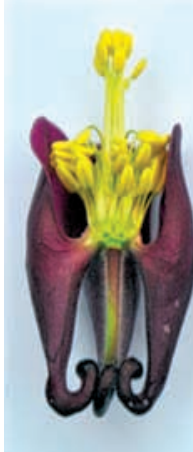

A

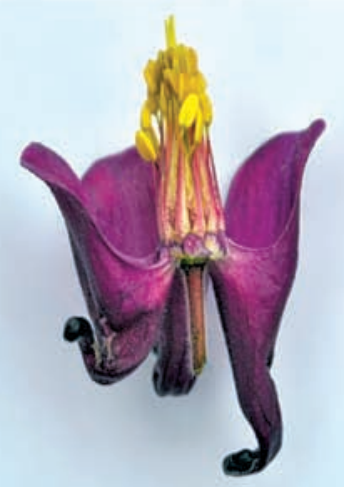

B
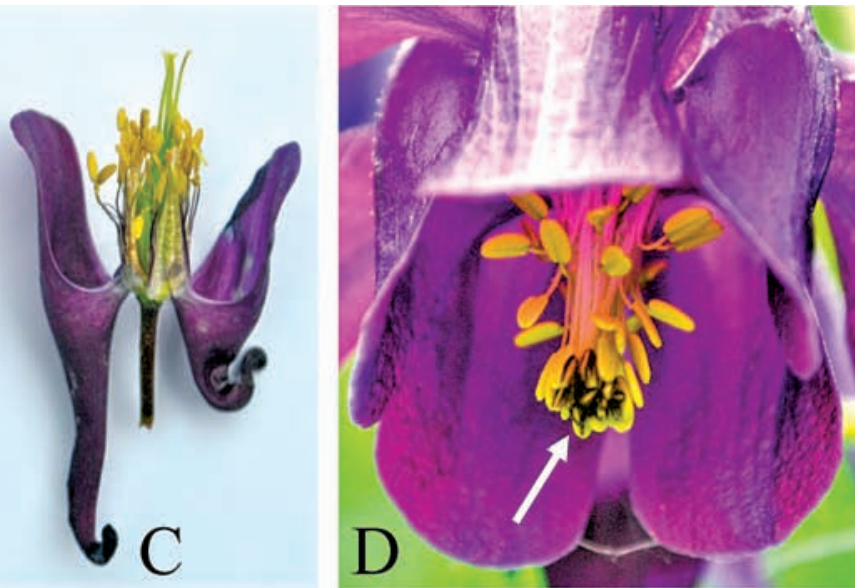

Fig. 3. Protandrous flowers of Aquilegia vulgaris L. (A) - 1st day of flower life-span, stigmas are not visible; (B) - 2nd day of flower life-span, pistils elongated above anthers; (C) - 4th day of flower life-span with c.a. all anthers dehisced, stigmas visible; (D) anthers start dehiscing from those situated in the inner part of the androecium (arrow). 


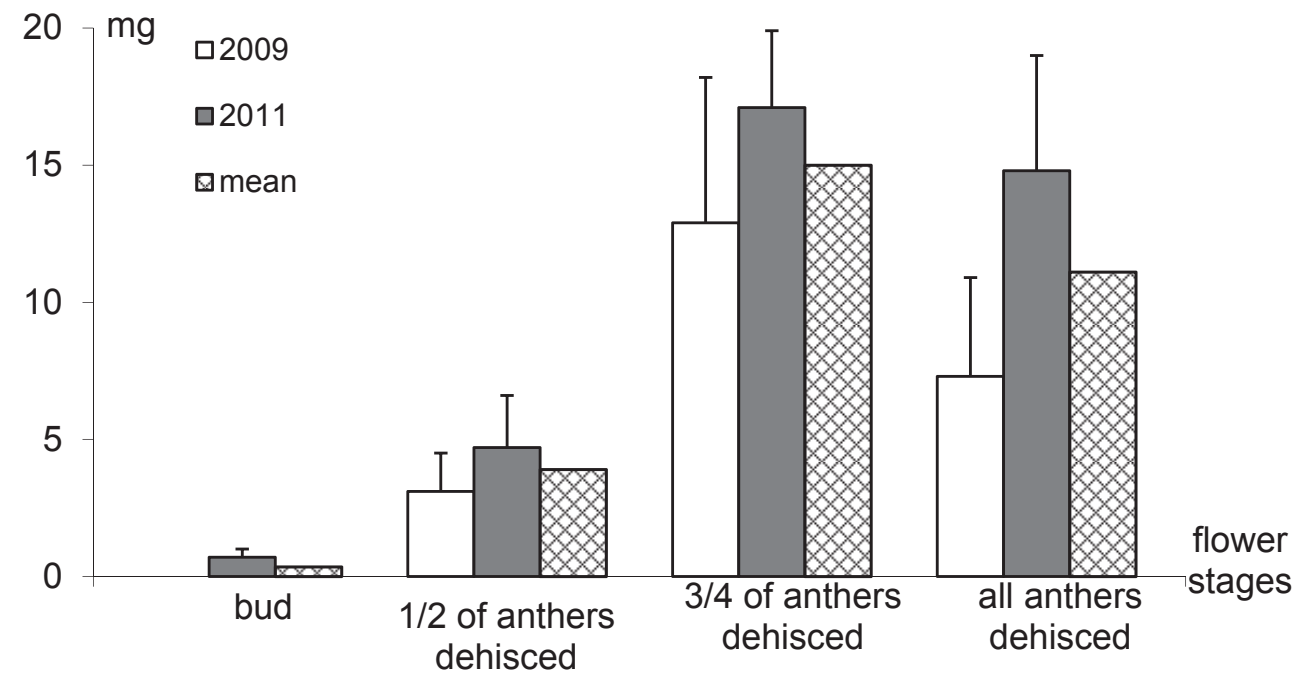

Fig. 4. Sugar mass per 10 flowers (in $\mathrm{mg}$ ) at the succesive stages of flower development in Aquilegia vulgaris L. Vertical bars indicate SD.

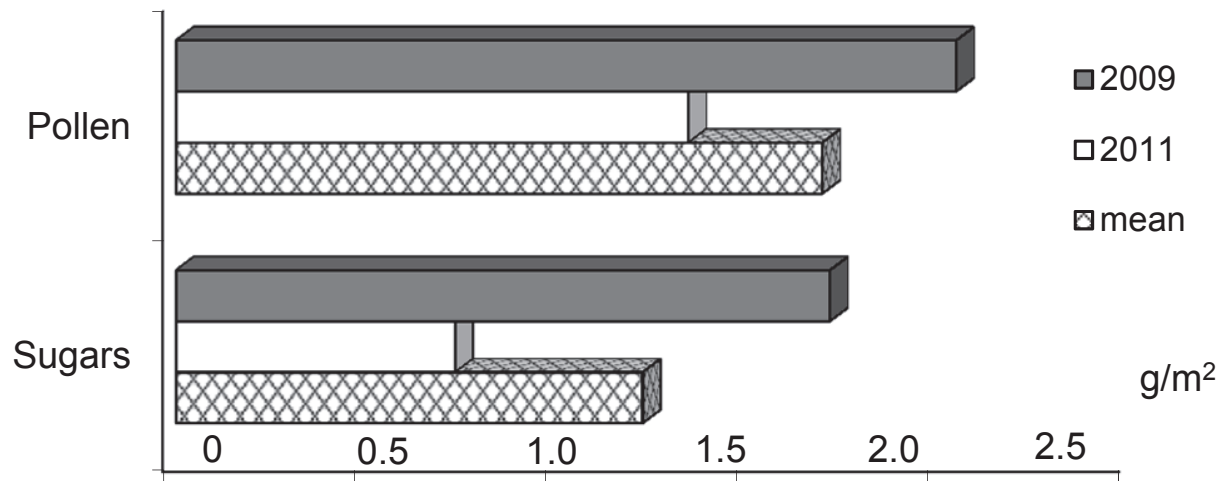

Fig. 5. Pollen and sugar yield of Aquilegia vulgaris cultivated in Lublin in 2009 and 2011.

\section{DISCUSSION}

The early flower opening pattern of the diurnal dynamics of blooming, characteristic for Aquilegia vulgaris L., varies from the one described for other species in the Ranunculaceae family ( $\mathrm{S} \mathrm{zk} \mathrm{lan} \mathrm{ow} \mathrm{-}$ ska, 1995; Żu raw and Denisow, 2002; Denis ow and Wrzes i en, 2006). The flowers of Aquilegia vulgaris start opening approx. $5.00(\mathrm{GMT}+2 \mathrm{~h})$, that is, 2-3 hours earlier than, e.g., Anemone japonica or Adonis vernalis L. This confirms that the diurnal dynamics of blooming is highly species-specific and, additionally, indicates an adaptation to different insect foraging patterns of depending on the growing season. Also, the adaptations to external abiotic factors can impact a specific blooming pattern during the day ( $\mathrm{De}$ nisow, 2009; Weryszko-Chmielewska and D mitruk, 2009).

The basic features that impact the plant-pollinator interaction are colour, size, symmetry, shape, and reward of the flower. Flowers of Aquilegia vulgaris are massive and have their nectar protected in long floral spurs to attract specialized pollinators. The main pollinators observed in our study were Bombus spp. Other insects were observed sporadically. According to Fus sell and Corbet (1992), species from the genus Bombus competing with other pollinators, e.g. honeybees, choose massive flowers and if additionally the reward features are attractive to bumblebees, they may exclude smaller foragers.

B. terrestris L. was the most frequently observed forager in Lublin. Med ra n o et al. (2006) documented mainly $B$. pascuorum and $B$. pratorum visiting A. vulgaris $\mathrm{L}$. in Spain. Insect visits on flowers depend not only on the accessible reward in individual flowers, but also on the density of patches and seasonal availability of alternative forage. Our study site was located in a botanical garden with an abundance of attractive co-flowering species on which different species of the genus Bombus foraged. Also, the differences in diversity of Bombus spp. and their population size in a given area may impact foraging participation and frequency of bumblebees. The floral spurs of Aquilegia vulgaris 
lengthen during flower development. This feature, together with the dynamics of nectar accumulation, may influence the selection of flowers by pollinators and attract short-tongue (e.g. B. terrestris) and long-tongue bumblebees (e.g. B. pascuorum and B. pratorum) at different times. In our study, the amount of nectar was the highest on the $3^{\text {rd }}$ day of anthesis and it was associated with the end of the male phase. Probably the dynamics of nectar secretion supports the pollination system of protandrous flowers and attracts bumblebees to visit the flower at the most appropriate time for effective pollination and to reduce the chance of self-pollination. A similar dynamics of nectar accumulation and resorption is known in the case of other plants (e.g. Orchidaceae) (S t p i c z y ń s ka, 2004). Additionally, the pattern of anther dehiscence encourages dichogamy. Pollen shed starts from anthers situated in the central part of the androecium and progresses outwards. Thus, the anthers positioned in contact with the styles release pollen before stigma receptivity. Usually, the process starts from the anthers situated in the outer parts of the androecium, as described by many authors for species in the Ranunculaceae family (S zk lanowska, 1995; Żu raw and Den is ow, 2002; S z k la n ow ska et al. 2003; De n i s ow and Wrzesień, 2006; R y siak and Ż uraw, 2011).

Sporadically, and exclusively in 2009, perforated floral spurs were found, but neither short-tongue bumblebees nor honeybees were observed to use this access to get the nectar reward. Nectar robbing is known in the case of different species with deeply hidden nectar (e.g. Symphytum officinale) (F a e g r i and van der Pij1, 1979).

In our study, approx. 1-2 nectaries per flower did not secrete nectar or the amount was too small and thus remained undetected by the method applied. This finding requires wider studies.

Most papers on pollination ecology focus on nectar reward. We also studied the pollen reward. The productivity of archespores expressed as the percentage of pollen in the total weight of dry pollen-containing anthers varied significantly between years (mean $=29.4 \%$ and $51.7 \%$, respectively). This indicates that this trait seems to be highly influenced by external factors differently than in other taxa e.g. ( $\mathrm{S} \mathrm{z} \mathrm{k} \mathrm{la} \mathrm{n} \mathrm{o} \mathrm{w} \mathrm{-}$ ska, 1995; Denis ow, 2011). The number of anthers was a more stable feature than the size of anthers. The amount of pollen produced in flowers $(3.28 \mathrm{mg}$ per flower) is comparable with other Ranunculaceae species with massive flowers (e.g. Adonis vernalis $\mathrm{L}$. or Anemone japonica) (D e n i s o w and W r ze s i eń, 2006; Denisow and B ożek, 2006; Denisow et al. 2008). According to De n is ow (2011), bumblebees forage mainly on flowers with a high mass of pollen produced per flower.
The flower features described in our study (flower size, deeply hidden nectar, dynamics of nectar secretion, pollen production, high pollen viability), together with sugar concentration and composition with the predominance of sucrose described by $\mathrm{C}$ a $\mathrm{n}$ to et al. (2007), indicate that Aquilegia vulgaris L. flowers are highly specialised for bumblebee pollination. On account of its decorative flowers, this species is worth cultivating in bumblebee-friendly gardens.

\section{Acknowledgements}

Research supported by the Ministry of Science and Higher Education of Poland as the part of statutory activities of Department of Botany, University of Life Sciences in Lublin.

\section{REFERENCES}

Baker H.G., 1975. Sugar concentrations in nectars from hummingbird flowers. Biotropica, 7: 37-41

Bożek M., 2003. Pollen efficiency and foraging by insect pollinators in three catnip (Nepeta L.) species. J. Apic. Sci. 47(2): 19-24.

Canto A., Perez R., Medrano M., Castellanos M.C., Herrera C.M., 2007. Intra-plant variation in nectar sugar composition in two Aquilegia species (Ranunculaceae): Contrasting patterns under field and glasshouse conditions. Ann. Bot. 99: 653-660.

Denisow B., 2009. Factors determining the diurnal dynamics of blooming of chosen plant species. Acta Agrobot. 62(1):83-89.

Denis ow B., 2011. Pollen production of selected ruderal plant species in the Lublin area. 351. Univ. Life Science Press, Lublin, 351: 86.

Denisow B., Bożek M., 2006. Blooming biology and pollen abundance of Anemone japonica Houtt. = Anemone x hybrida hort. Acta Agrobot. 59(1): 139-146. (in Polish).

Denisow B., Wrzesień M., 2006. The study of blooming and pollen efficiency of Adonis vernalis L. in xerothermic plant communities. J. Apicul. Sci. 50(1): 25-32.

Denisow B., Wrzesień M., Cwener A., 2008. The estimation of Adonis vernalis populations in chosen patches of Lublin Upland. Acta Agrobot. 61(1): 3-11.

Faegri K., van der Pijl L., 1979. The principles of pollination ecology. Pergamon Press, London, 58-63.

Fussell M., Corbet SA., 1992. Flower usage by bumble-bees: a basis for forage plant management. J. Appl. Ecol. 29: 451-465.

Jabłoński B., 2002. Notes on the method to investigate nectar secretion rate in flowers. J. Apicul. Sci. 46 (2): 117-125.

Kocira A., Laskowska H., 2006. Ocena walorów dekoracyjnych Acidanthera bicolor var. murielae Perry 
traktowanej biostymulatorami. / Evaluation of the ornamental values of Acidanthera bicolor var. murielae Perry treated with biostimulators. Zesz. Probl. Post. Nauk Roln. 510: 275-280. (in Polish)

Lavergne S., Debussche M., Thompson J.D., 2005. Limitations on reproductive success in endemic Aquilegia viscosa (Ranunculaceae) relative to its widespread congener Aquilegia vulgaris: the interplay of herbivory and pollination. Oecologia, 142: 212-220.

Medrano M., Castellanos M.C., Herrera C.M., 2006. Comparative floral and vegetative differentiation between two European Aquilegia taxa along a narrow contact zone. Plant Syst. Evol. 262: 209-224.

Percival M.S ., 1961. Types of nectar in angiosperms. New Phytologist, 60(3): 235-281.

Rysiak K., Żuraw B., 2011. The biology of flowering of winter aconite (Eranthis hyemalis (L.) Salisb.). Acta Agrobot. 64(2):25-32.

St piczyńska M., 2004. Rola nektaru w kwiatach podkolana zielonawego Platanthera chlorantha (Custer) Rchb. (Orchidaceae). / The role of nectar in the flowers of Platanthera chlorantha (Custer) Rchb. (Orchidaceae). Agricultural Academy, Lublin 286: 33-38. (in Polish)

Szk lanowska K., 1995. Pollen flows of crowfoot family (Ranunculaceae L.) from some natural plant communities. [In:] Changes in fauna of wild bees in Europe. Pedagogical Univ.Bydgoszcz: 201-209.

Szklanowska K., Strzałkowska M., Łuczywek R., 2003. Kwitnienie, pylenie i oblot przez pszczołę miodną trzech gatunków sasanki (Pulsatilla Mill.). / Flowering, pollen production and foraging by honey bees of three species of pasque flower (Pulsatilla Mill.). Ann. Univ. Mariae Curie-Skłodowska, Sect. EEE Hortic. 12: 59-66. (in Polish)

Weryszko-Chmielewska E., Dmitruk M., 2009. Characteristics of blooming, floral nectaries and nectar of Malus sargentii Rehd. Acta Agrobot. 62(1): 17-25.

Wróblewska A., 2010. Flowering dynamics, nectar secretion and insect visitation of Phacelia campanularia A. Gray. Acta Agrobot. 63(1): 29-35.

Żuraw B., Denisow B., 2002. Biologia kwitnienia i pylenie kwiatów z rodzaju Helleborus L. / Blooming biology and pollen release in Helleborus L. Ann. Univ. Mariae Curie-Skłodowska, Sect. EEE, Hortic. 10: 45-50 (in Polish).

$\dot{Z}$ u raw B ., 2011. Flowering biology of three taxa of the genus Scilla (Hyacinthaceae) and flower visitation by pollinating insects. Acta Agrobot. 64(1):12-17.

\section{Kwitnienie, sekrecja nektaru, pylenie oraz oblot przez owady kwiatów Aquilegia vulgaris L. (Ranunculaceae)}

\section{Streszczenie}

Badania biologii kwitnienia, nektarowania, pylenia oraz oblotu przez owady orlika pospolitego (Aquilegia vulgaris L.) prowadzono w latach 2009 i 2011 w Lublinie. W ciągu dnia szczyt kwitnienia przypada w godzinach pomiędzy 5.00 a 7.00 (GMT +2 ). W protandrycznych kwiatach faza funkcjonalnie żeńska rozpoczyna się przeciętnie w 3 dniu życia kwiatu. Dynamika sekrecji nektaru oraz uwalnianie pyłku z pylników (postępujące od wewnątrz do zewnątrz androecium) wspomagają system reprodukcyjny gatunku. Ilość nektaru gromadzonego w ostrogach wzrasta sukcesywnie od stadium pąka i maksymalną wartość osiąga w fazie, gdy przeciętnie l' pylników w kwiecie zakończyło już proces pylenia. Od tego momentu ilość gromadzonego $\mathrm{w}$ kwiatach nektaru spadała. Liczba pylników w kwiatach waha się od 41 do 61 (średnio $=49.1$ ). Przeciętna masa produkowanego pyłku wynosi 6,7 mg ze 100 pylników oraz 3,28 mg z 10 kwiatów. Pomiędzy latami badań wystąiły wahania masy pyłku dostarczanego przez kwiaty, co korelowało dodatnio ze zmienną liczbą wytwarzanych pręcików. Oszaco-

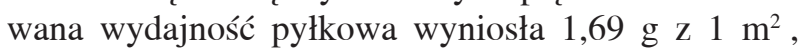
a cukrowa $1,22 \mathrm{~g} \mathrm{z} 1 \mathrm{~m}^{2}$. Gatunki z rodzaju Bombus były głównymi owadami wizytującymi kwiaty, a Bombus terrestris pojawiał się z najwyższą frekwencją. 